可視化情報 Vol.20 Suppl. No.1（2００００年 7月）

田畑 隆英（鹿児島高専），中島 正弘（鹿児島高専） 李 輝 (鹿児島大学), 野㟝 勉 (鹿児島大学)

\title{
Wavelet Analysis Applied to Circular Wall Jet
}

\author{
Takahide TABATA, Masahiro NAKASHIMA, Hui LI and Tsutomu NOZAKI
}

\begin{abstract}
In this report, the wavelet intermittency based on wavelet transform is newly applied to reveal the intermittent phenomenon of the circular jet issuing along the cylinder wall. The wavelet intermittency provides simultaneously the information of intermittency over a time and period region. The flow structure of the wall jet was clarified using the wavelet intermittency, comparing with that of the plane wall jet.
\end{abstract}

Keywords: Wall jet, Turbulent flow, Wavelet analysis, Intermittency, Visualization

\section{1. 緒 論}

壁面に沿って流出寸る噴流は広く工学的に応用されて おり，この壁面噴流に関寸る研究も多くなされている。

著者らは大口径円管の内壁または円筒形物体の外壁に沿 い，しかも軸方向に流出寸る円形噴流に関寸る研究を行 っている。ここでは，前報1に引き続き，噴流の間欠現 象在明らかにするために，間欠ウェーブレット係数を新 たに適用し，円筒形物体の外壁に沿って流出寸る噴流と 平板壁に沿って流出する噴流との相違を比較したので報 告する。

\section{2. 実験装置および方法}

本研究で用いた実験装置の概略を図 1 に示寸。送風機 からの空気は，鎮静胴を通り，内径 $d=20 \mathrm{~mm}$ の円管から 直径 $D=500 \mathrm{~mm}$, 長さ $1000 \mathrm{~mm}$ のアクリル樹脂製円管の外 壁面に沿って流出する。速度の測定にはI形およびX形 熱線センサーと定温度形熱線流速計を用いた。なお，空 間相関などの測定の場合にはX形センサー 2 本と熱線流 速計 2 台を用いた。本実験において円管出口における最

(1)Blower (2)Plenum chamber (3)Circular pipe (4)Cylindrical wall (5)Hot wire sensors (6)CTA systems (7)Personal computer (8)CD unit

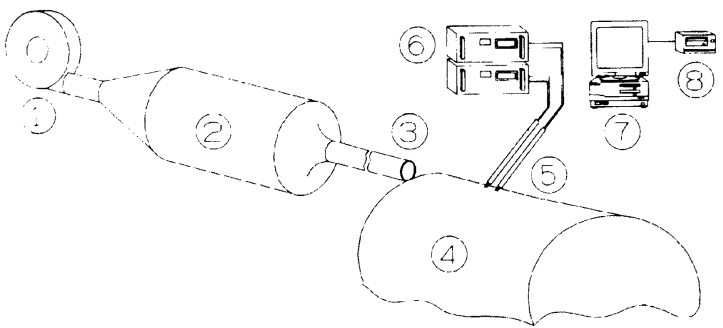

Fig. 1 Experimental apparatus
大速度 $U_{11}$ とdを用いて表したレイノルズ数は約 $4.02 \times 10^{+}$である.

流れのモデルと座標采を図 2 に示す。噴流が流出する 円管出口の壁面上に座標原点 $o$ をり，各座標軸 $x, y$, zを図のようにとる。また, 各軸方向の速度成分 を $u, v, w$ とし, 半值幅などの各特性量を図のようにと る.

\section{3.ウェーブレット間欠係数}

間欠係数は，乱流に含まれる渦塊の通過する時間と乙 うでない時間の比で定義されているが，一般にそれを求 めることは困難であり，かつ間欠現象のスケールの情報 を得ることはできない.

そこで，本研究では流れの大規模構造に含まれる間欠 現象のスケールと出現時間を調査するために,式(1)で示 されるFarge ")が提案したウェーブレット間欠係数

$$
W I(b . a)=\frac{|W f(b . a)|^{2}}{\int_{x}|W f(b . a)|^{2} d t}
$$

を新たに適用した。このウェーブレット間欠係数WI(b.a)

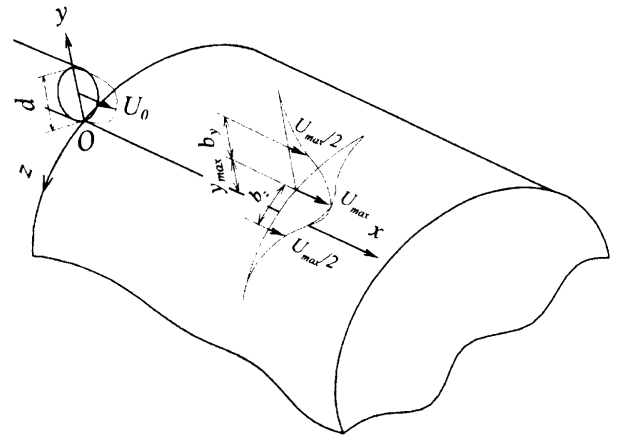

Fig. 2 Schematic model 
は，平均のスペクトルに対する任意のスケール $a$ および 位置 $b$ における瞬間のエネルギの割合を示す。なお，本 研究におけるウェーブレット変換Wf(b,a)およびアナラ イジングウェーブレットの定義については, 既報 ${ }^{3)}$ に詳 しく述べられているので,ここでは省略する.

\section{4. 実験結果および考察}

噴流の間欠現象を調べるために，下流位置 $x / d=40$ の 測定点における速度変動成分 $u^{\prime}$ のウェーブレット間久 係数 $W I(a, t)$ を求めた。平板壁面噴流および円筒壁面噴流 のウェーブレット間欠係数をそれぞれ図 3 および図 4 に 示す.上図において横軸は時刻 $t$, 縦軸は周期 $a$, そし てカラーの変化は $W I(a, t)$ の大きさ示す，また，下図に 速度変動波形を示寸。

図 3 に示寸平板壁面噴流において, 赤で示す $W I(a, t)$ の ピークは, $a=0.1 \mathrm{~s} か つ t=0.8 \sim 1.2 ， 2.2 \sim 2.5 \mathrm{~s}$ に間欠的 に現れ，両者とも $0.2 \mathrm{~s}$ 程度持続している。また， $a=0.04 \sim 0.05 \mathrm{~s}$ において $0.1 \mathrm{~s}$ 程度持続寸るピークが 2 , 3 回連続して現れでは消えるという現象を間欠的に繰り 返している。すなわち，2つの周期成分を有する変動が， 計測点を間欠的に通過していることを示している.

一方，図4に示す同じ下流位置における円筒壁面噴流 の場合, $W I(a, t)$ のピークは $a=0.14 \mathrm{~s}$ かつ $t=2.4 \sim 2.7 \mathrm{~s}$ に現れ， $0.4 \mathrm{~s}$ 程度持続している。また， $a=0.06 \mathrm{~s}$ にお いて $0.1 \mathrm{~s}$ 程度持続するピークが $t=2.2 \sim 2.9 \mathrm{~s}$ に 3 回現れ ている、したがって，円筒壁面噴流の流れは，平板壁面 噴流と比較して間欠的であり, 間欠現象の周期成分は若 干長めで，しかもその持続時間も長くなっていることが わかる。

次に, 円筒壁面噴流の下流位置 $x / d=40, z=b_{z}$, $y=y_{\text {max }}$ の測定点におけるWI $(a, t)$ を図 5 に示寸. WI $(a, t)$ のピークは $a=0.15 \mathrm{~s}$ かつ $t=0.2 \sim 0.4 \mathrm{~s}$ に現れ, かつ $a=0.04 \sim 0.12 \mathrm{~s}$ に様々な持続時間を有するピークが時間 の経過とともに継続的に出現している。これは計測点を 通過する流れに様々な周期成分を有する変動が含まれて いることを示している，また，大きなエネルギを有する 現象の周期成分に着目すると， $y=b_{y}$ 、である図 4 におい ては $a=0.14,0.06 \mathrm{~s}$ であるが， $y=y_{\text {max }}$ である図 5 にお いては $a=0.05 \sim 0.08 \mathrm{~s}$ である.したがって $y=b_{y}$.ではよ り長い周期成分を持つ大規模な変動が長い時間間隔で間 欠的に出現していることを意味している。

\section{5. 結 言}

新たに導入したウェーブレット閒欠係数により噴流の 構造を考察した. その結果, ウェーブレット間欠倸数を 用いることにより，流れに含まれる間欠現象のスケール 之持続時間を抽出し，円筒形物体の外壁に沿って流出寸 る噴流と平板壁に沿って流出する噴流の構造に相違があ ることを明らかにした。

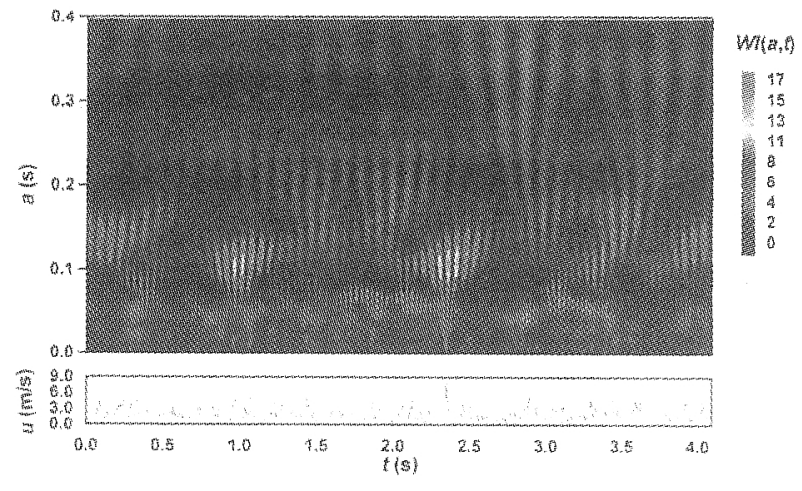

Fig. 3 Wavelet Intermittency Analysis of $u^{\prime}$ (Plane wall jet at $x / d=40, y=b_{r}, z=b_{z}$ )

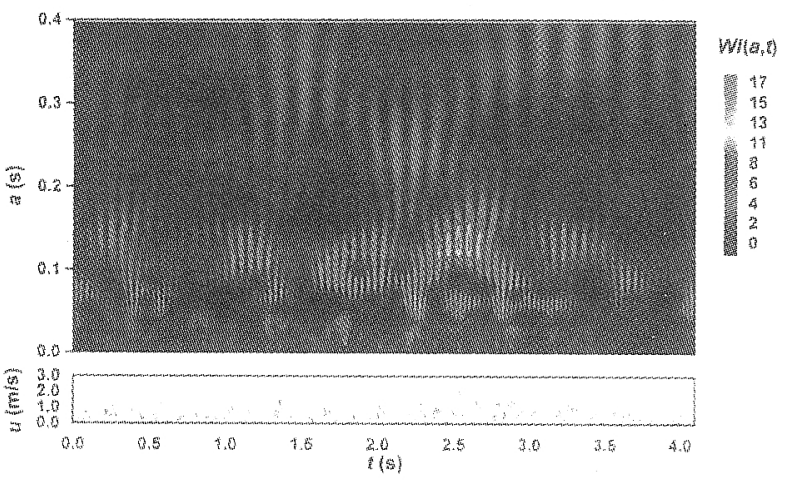

Fig. 4 Wavelet Intermittency Analysis of $u^{\prime}$ (Circular wall jet at $x / d=40, y=b_{y,}, z=b_{z}$ )

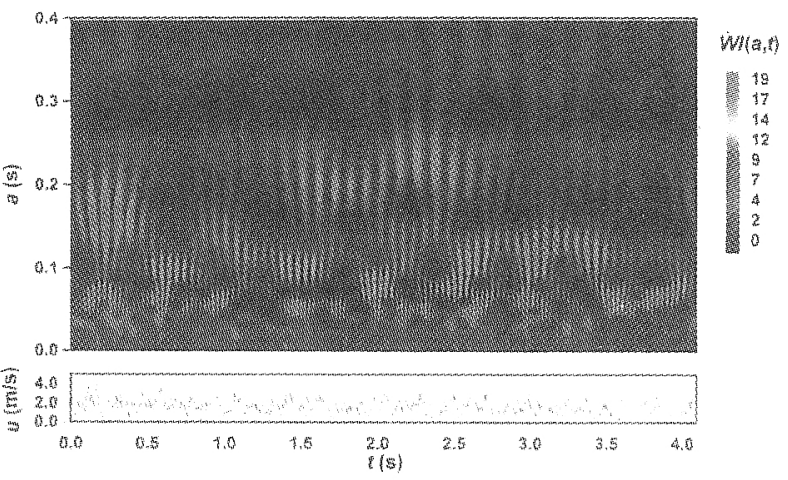

Fig. 5 Wavelet Intermittency Analysis of $u^{\prime}$ (Circular wall jet at $x / d=40, y=y_{\max }, z=b_{z}$ )

\section{参 考 文 献}

1）田畑隆英 -中島正弘・李輝 - 野㟝勉：円形壁面噴流のウェ ーブレット解析, 可視化情報, Vol.19, Suppl.No.1(1999), pp.31-32.

2) Farge, M. : Wavelet Transforms and Their Applications to Turbulence, Annual Review of Fluid Mechanics, Vol.24, (1992) pp.395-457.

3) Li, H. and Nozaki, T: Wavelet Analysis for the Plane Turbulent Jet (Analysis of Large Eddy Structure), Transactions of JSME International Journal, Fluids and Thermal Engineering, 38-4, (1995), pp.525-531. 